\title{
Improvement Some Soil Properties by Using Lime and Cement at Different Percentages
}

\author{
Elaf Jassim Mahan', Anas Kareem Hussein² \\ ${ }^{1,2}$ Al-Mustaqbal University College, Civil Engineering Department, Iraq, Babil, Hilla
}

\begin{abstract}
The Treatment of soils using lime and cement is one of the appropriate techniques that provides solutions for poor geotechnical soils used in road construction. The main objective of this study is to improve some soil properties such as (water content, dry denisity, liquid limit, plastic limit) at different additive percents and two types of additive. In this researchsoilsampleswere testedin thestandardcasewithoutadditiveand with theadditive, two types ofadditiveshas been used(cement and lime). The test procedure and test results conducted on original soil and treated soilare presented. Soil-lime mixtures and soil-cement mixture were tested with three percentages of each cement and lime $(3 \%, 6 \%, 9 \%)$ from soil dry weight and one of these percentages is the optimum additive content $6 \%$ cement, $6 \%$ lime. From our result we found that $6 \%$ cement was the optimum additive (percent and type).
\end{abstract}

Keywords: soil, lime, cement, atterberglimits, OMC and MDD

\section{Introduction}

Soil improvement is the process of the alteration of the geotechnical properties to satisfy the engineering requirements [1]. Many types of stabilizers were used as soil additives to improve its engineering properties. A number of stabilizers, such as cement, lime and fly ash, depend on their chemical reactions with the soil elements in the presence of water [2],[3] and [4]. Other additives, such as geofiber and geogrid, depend on their physical effects to improve soil properties [5].The methods of soil modification or stabilization include physical processes such as soil densification, blends with granular material, use of reinforcements (Geogrids), undercutting and replacement, and chemical processes such as mixing with cement, fly ash, lime, lime byproducts, and blends of any one of these materials. Soil properties such as strength, compressibility, hydraulic conductivity, workability, swelling potential, and volume change tendencies may be altered by various soil modification or stabilization methods, ( The Indiana Department of Transportation) INDOT standard specifications provide the contractor options on construction practices to achieve soil modification that includes chemical modification, replacement with aggregates, geosynthetic reinforcement in conjunction with the aggregates, and density and moisture controls. Geotechnical designers have to evaluate the needs of the subgrade and include where necessary, specific treatment above and beyond the standard specifications. It is necessary for designers to take into consideration the local economic factors as well as environmental conditions and project location in order to make prudent decisions for design[6].The purpose of soil modification is to create a working platform for construction equipment. The most common improvements achieved through stabilization include [7]:

- Reducing plasticity index.

- Reducing swelling potential.

- Increasing durability and strength.

- Waterproofing the soil.

- Drying of wet soils.

- Conserving aggregate materials.

- Reducing cost of construction.

\section{Materials and Methodology Used}

The following materials have been used in this research with specific properties as mentioned below:

\subsection{Soil}

The soil sample was obtained from AL-Mustaqbl university college to the south of Al-Hilla city center. When the samples are obtained, the superficial soil was scraped off in order to dispose the organic materials and roots then, disturbed soil samples obtained from the site. Tables(1and 2)show chemical andphysical properties respectively for the original soil

Table 1: Chemical Properties of The Original Soil

\begin{tabular}{|c|c|}
\hline Chemical properties & Value \\
\hline Sulphate Content $\%$ & 1.2 \\
\hline Gypsum Content \% & 2.58 \\
\hline Total Soluble Salts Test $\%$ & $2.97 \mathrm{~g} / \mathrm{L}$ \\
\hline Chlorides CL & $57.81 \mathrm{meq} / \mathrm{L}$ \\
\hline Organic Matter Content $\%$ & $0.90 \mathrm{~g} / \mathrm{kg}$ \\
\hline PH-Value & 8.1 \\
\hline $\mathrm{Ca}++$ & $7.5 \mathrm{meq} / \mathrm{L}$ \\
\hline $\mathrm{Mg}++$ & $6 \mathrm{meq} / \mathrm{L}$. \\
\hline
\end{tabular}

Table 2: Physical Properties of The Original Soil.

\begin{tabular}{|c|c|}
\hline Soil Properties & Original Soil \\
\hline LL \% & 43 \\
\hline PL \% & 25 \\
\hline PI \% & 18 \\
\hline Water Content (\%) & 21.0 \\
\hline Specific Gravity & 2.73 \\
\hline O.M.C $(\%)$ & 20 \\
\hline M.D.D $\left(\mathrm{gm} / \mathrm{cm}^{3}\right)$ & 1.9 \\
\hline$\%$ of Fines & 94.5 \\
\hline AASHTO Classification & A6 \\
\hline Unified Classification & Silty Clay \\
\hline
\end{tabular}

\subsection{Additives}

Two types of additives are used in this research, lime and cement. 


\section{International Journal of Science and Research (IJSR) \\ ISSN (Online): 2319-7064}

Index Copernicus Value (2016): 79.57 | Impact Factor (2015): 6.391

a)Lime

The lime used in this work is Hydrated lime $\mathrm{Ca}(\mathrm{OH}) 2$ from Kofa-lime factoryin Iraq. The lime to be used may be either hydrated or quicklime, although most stabilization is done using hydrated lime. The reason is that quicklime is highly caustic and dangerous to use. Table (3) shows the chemical composition of hydrated lime that is tested according to the I.O.S standard, No. 807, 1989.

Table 3: Chemical composition for lime used in the study

\begin{tabular}{|c|c|c|}
\hline Properties & Value $(\%)$ & I.O.S standard \\
\hline Activity & 71.67 & ---- \\
\hline $\mathrm{CO}_{2} \%$ & 1.73 & $\leq 5 \%$ \\
\hline $\mathrm{Mg} \%+\mathrm{CaO} \%$ & 88.5 & $\geq 64 \%$ \\
\hline $\mathrm{MgO} \%$ & 0.41 & $\leq 5 \%$ \\
\hline $\mathrm{Fe}_{2} \mathrm{O}_{3} \%$ & 0.13 & \multirow{4}{*}{$\begin{array}{c}\text { Summation of } \\
\text { oxide } \leq 5 \%\end{array}$} \\
\hline $\mathrm{Al}_{2} \mathrm{O}_{3} \%$ & 0.85 & \\
\hline $\mathrm{SiO}_{2} \%$ & 1.47 & \\
\hline $\mathrm{SO}_{3} \%$ & 0.34 & \\
\hline L.O.I(Loss Of Ignition) & 23.41 & ----- \\
\hline $90 \mu$ ( Retained On Sieve) & 3.22 & $\leq 10 \%$ \\
\hline $\mathrm{Ca}(\mathrm{OH}) 2 \%$ & 87.22 & ---- \\
\hline
\end{tabular}

\section{b) Cement:}

Sulphate resistance Portland cement (Jeser) has been used in this research. In order to obtained chemical and physical properties, chemical and physical tests have been done. The tests held according to I.O.S standard, No. 5, 1984. Tables (4) and (5) show these chemical and physical properties, respectively.

Table 4: Chemical properties of Sulphate resistance portland cement

\begin{tabular}{|c|c|c|}
\hline Composition & Test Results & $\begin{array}{l}\text { Limits According } \\
\text { to I.O.S }\end{array}$ \\
\hline $\mathrm{CaO} \%$ & 60.71 & \\
\hline $\mathrm{SiO}_{2} \%$ & 18.5 & \\
\hline $\mathrm{Al}_{2} \mathrm{O}_{3} \%$ & 4.37 & \\
\hline $\mathrm{Fe}_{2} \mathrm{O}_{3} \%$ & 5.2 & \\
\hline $\mathrm{MgO} \%$ & 2.17 & $\leq 5 \%$ \\
\hline $\mathrm{SO}_{3} \%$ & 1.85 & $\begin{array}{c}\leq 2.5 \% \text { if } \\
\mathrm{C} 3 \mathrm{~A}<5 \% \\
\leq 2.8 \% \\
\text { if } \mathrm{C} 3 \mathrm{~A}>5 \%\end{array}$ \\
\hline Insoluble Residue \% & 0.94 & $\leq 4 \%$ \\
\hline TOTAL & 93.74 & \\
\hline Properties & Test Results & $\begin{array}{c}\text { Limits According } \\
\text { to I.O.S }\end{array}$ \\
\hline Free Lime $\%$ & 0.76 & \\
\hline Insoluble Residue \% & 0.67 & $\leq 1.5 \%$ \\
\hline L.S.F. Lime Saturation Factor & 0.75 & $0.66-1.02$ \\
\hline Modulus Silica & 2.45 & \\
\hline Modulus Alumina & 0.86 & \\
\hline $\mathrm{C} 3 \mathrm{~S} \%$ & 51.85 & \\
\hline $\mathrm{C} 2 \mathrm{~S} \%$ & 22.4 & \\
\hline $\mathrm{C} 3 \mathrm{~A} \%$ & 2.93 & $\leq 3.5 \%$ \\
\hline $\mathrm{C} 4 \mathrm{AF} \%$ & 14.10 & \\
\hline
\end{tabular}

Table 5: Physical properties of Sulphate resistance portland cement

\begin{tabular}{|c|c|c|c|}
\hline Properties & \multicolumn{2}{|c|}{ Test Result } & $\begin{array}{c}\text { Limits According } \\
\text { to I.O.S }\end{array}$ \\
\hline \multirow{2}{*}{ Setting Time (min.) } & Initial & 126 & $\geq 45 \mathrm{~min}$ \\
\cline { 2 - 4 } & Final & 226 & $\leq 600 \mathrm{~min}$ \\
\hline Fineness (Blaine) in $\mathrm{m}^{2} / \mathrm{Kg}$ & \multicolumn{2}{|c|}{313} & $\geq 230$ \\
\hline
\end{tabular}

\begin{tabular}{|c|c|c|c|}
\hline Compressive Strength & 3 days & 19.5 & $\geq 15$ \\
\cline { 2 - 4 } MN $/ \mathrm{m}^{2}:$ & 7 days & 28.0 & $\geq 23$ \\
\hline
\end{tabular}

c) Water: Water shall be tested in accordance with and shall meet the suggested requirements of AASHTO T-26[8]. Water known to be of potable quality may be used without testing. Distilled Water is used in specific gravity and hydrometer tests. For other tests and curing, tap water has been used. Table (6) shows the chemical properties for tap water.

Table 6: Chemical properties for tap water

\begin{tabular}{|c|c|}
\hline Property & Value \\
\hline PH & 7.7 \\
\hline EC & $970 \mathrm{Mus}$ \\
\hline Turbidity & $275 \mathrm{mg} / \mathrm{L}$ \\
\hline $\begin{array}{c}\text { Total Hardness } \\
\text { Hardness(T.H) }\end{array}$ & $110 \mathrm{mg} / \mathrm{L}$ \\
\hline Chloride & $13.44 \mathrm{mg} / \mathrm{L}$ \\
\hline $\mathrm{Mg}$ & $215 \mathrm{mg} / \mathrm{L}$ \\
\hline $\mathrm{Ca}$ & $181.8 \mathrm{mg} / \mathrm{L}$ \\
\hline $\mathrm{SO} 4$ & $0.29 \mathrm{mg} / \mathrm{L}$ \\
\hline PO4 & $75 \mathrm{mg} / \mathrm{L}$ \\
\hline $\mathrm{Na}$ & $3.9 \mathrm{mg} / \mathrm{L}$ \\
\hline $\mathrm{K}$ & $480 \mathrm{mg} / \mathrm{L}$ \\
\hline TDS &
\end{tabular}

\section{Testing Program}

The testing program in this study can be summarized aschemical and physical tests.

\subsection{Chemical Tests}

The chemical tests include: PH-value, sulphate content $\mathrm{SO}_{3, \text { gypsumcontent, Total Soluble Salts Test }}$

\subsection{Physical Tests}

Such as this tests include: water content, specific gravity, grain size analysis, hydrometer, atterberg limits and maximum dry density. The classification of selected soil was carried out according to AASHTO soil classification and also to Unified Soil Classification System (U.S.C.S.) ASTM D2487. These two classification systems depend on atterberg limits and grain size distribution tests, Figure (1) represent Grain size distribution of the original soil.

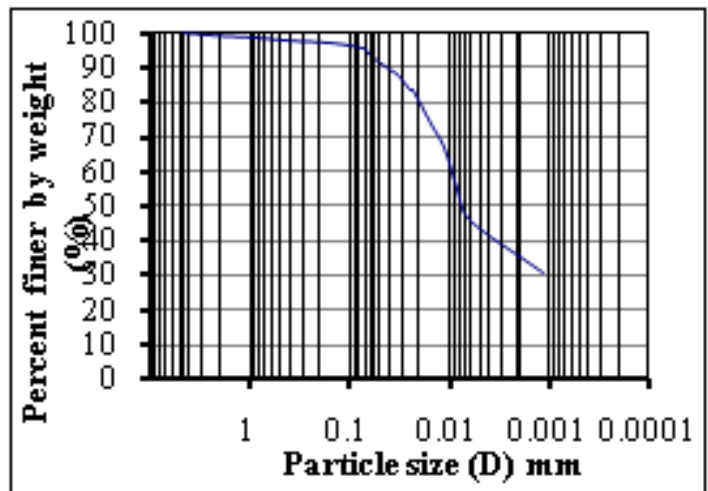

Figure 1: Grain size distribution of the original soil

\section{Volume 6 Issue 12, December 2017




\section{International Journal of Science and Research (IJSR) \\ ISSN (Online): 2319-7064 \\ Index Copernicus Value (2016): 79.57 | Impact Factor (2015): 6.391}

\section{Maximum Dry Density:}

Maximum dry density test was performed according to ASTM D-698 standard Procter test. These tests were used on original soil without additive and soil with additives(cement, lime) at different percentages of additives $(3,6,9) \%$.

\section{Atterberg Limits}

The liquid limit and the plastic limit tests for original soil and soil with additives (lime, cement) were carried out according to the ASTM D-4318 as shown in Figure(2). In this research the soil was dry mixed with the additive (lime, cement) and allowed to mellow prior to initiating the test. The percentages of additive were $(3 \%, 6 \%, 9 \%)$ from the weight of soil.

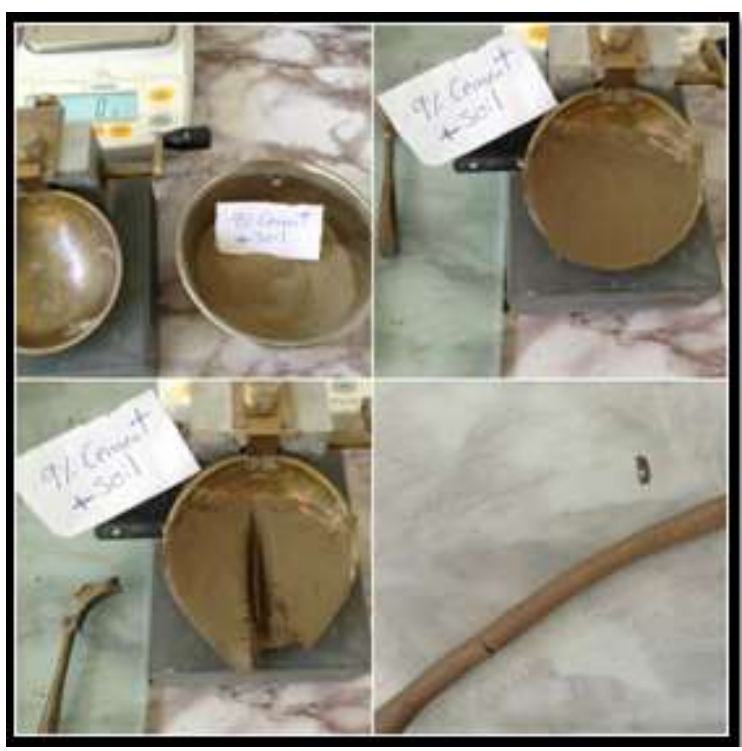

Figure 2: Atterberg Limits test at 9\%lime

\section{Results and Discussions}

\subsection{Effect of Additive Type and Percent on Atterberg Limits}

In order to investigates the effect of additive type and additive percent on atterberg limits(LL,PL,PI),specimens of the original soil were fabricated at three different percentages of additive $(3 \%, 6 \%, 9 \%)$ and two types of additive(lime and cement) and then made comparison between them. The obtained results for these comparisons are presented in Figures (3) to (8). In these Figures, indicate that initially liquid limit of the soil-cement mixture specimens increased slightly at the addition of $3 \%$ cement and after which liquid limit decreased with an increase in cement content. In other words, cement caused the maximum increase in liquid limit at the addition of $6 \%$ cement. While plastic limit increased slightly relatively constant. Consequently the plasticity index of soil-cement mixture increased initially (in cement content equal to $3 \%$ ) followed by a decrease with increasing of cement content especially at ( $6 \%$ cement). For the soil-lime mixture specimens Figures (6) to (8) indicate the variation of the liquid limit, plastics limit and plasticity index. According to the tests results, the liquid limit and plastic limit of the soil-lime mixture increased slightly due to increasing of lime content. Also with lime added to make up approximately $3 \%$, plasticity index starts to increases slightly and soil samples maintained an overall decrease in plasticity index by the further addition of lime. From these comparison it's clear that $6 \%$ is best percent for both additives(lime and cement) but cement shows more reduction in the plasticity index(PI).

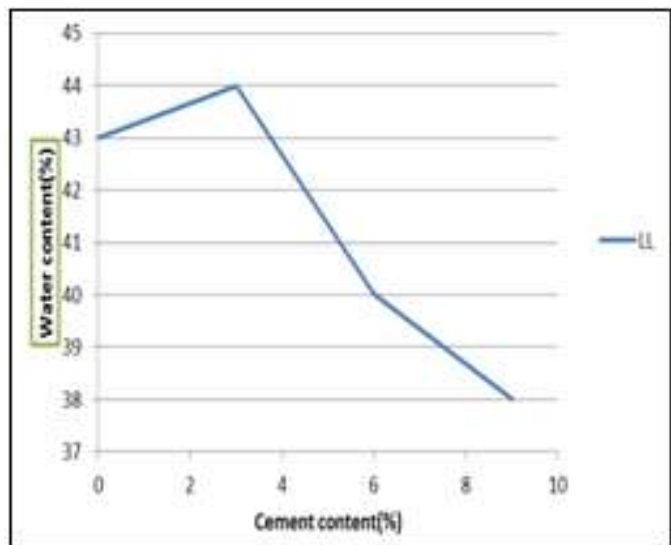

Figure 3: Liquid limit of cement-soil mixture at different percentages

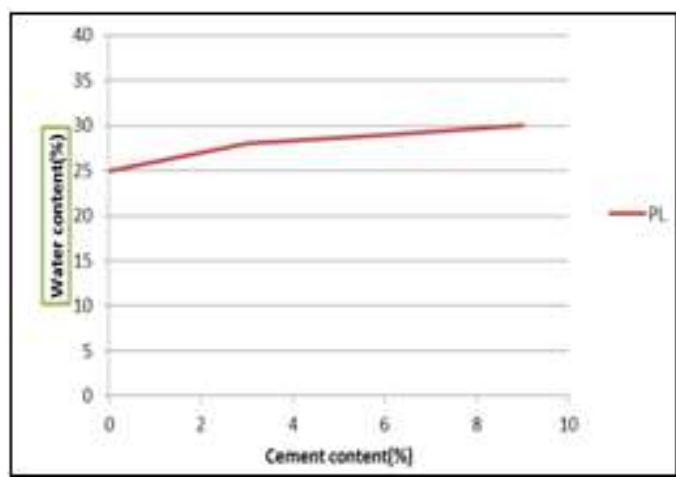

Figure 4: Plastic limit for soil-cement mixture at different percentages.

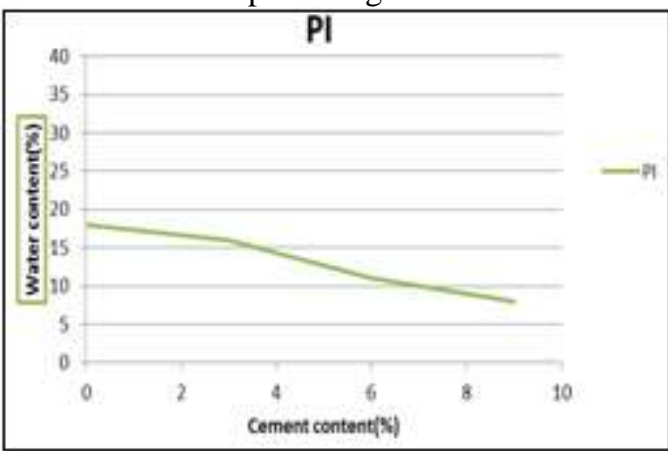

Figure 5: Plasticity Index for soil-cement mixture at different percentages.

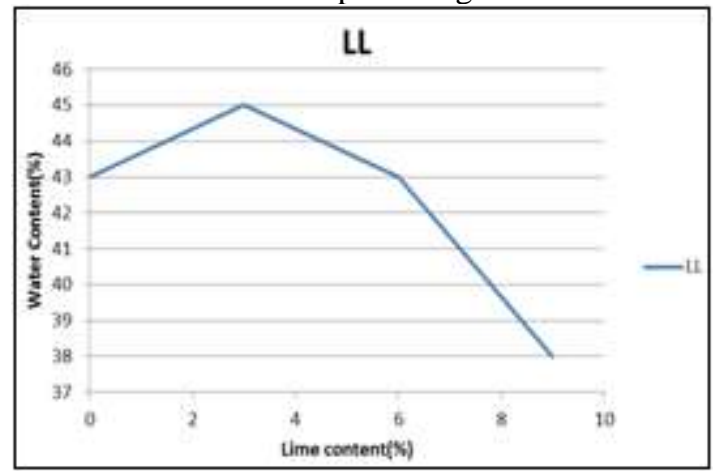

Figure 6: Liquid limit for soil-lime mixture at different percentages.

Volume 6 Issue 12, December 2017 
International Journal of Science and Research (IJSR)

ISSN (Online): 2319-7064

Index Copernicus Value (2016): 79.57 | Impact Factor (2015): 6.391

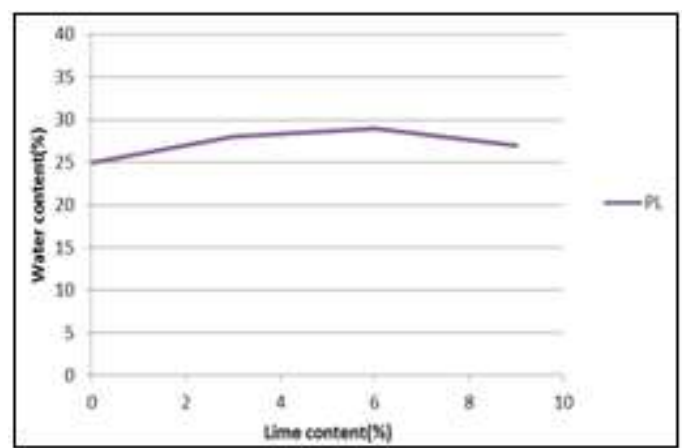

Figure 7: Plastic limit for soil-lime mixture at different percentages.

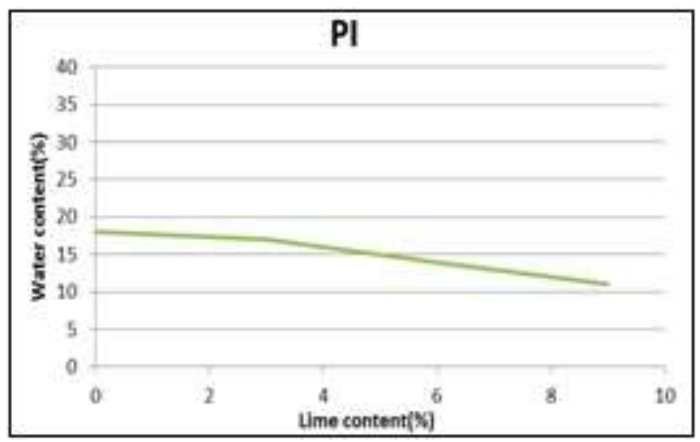

Figure 8: Plasticity Index for soil-lime mixture at different percentages.

\subsection{Effect of Additive Percent and type on Proctor (Compaction) Test}

Figures (9) to (12) demonstrate the effect of theadditive percent and type on Procter test for soil-cement mixture and soil-lime mixture respectively.

It can be seen from these Figures that at the addition of $6 \%$ cement and $6 \%$ lime, we will have minimum value of optimum moisture content and maximum value of dried specific weight. However this value is less than specific weightof untreated soil. Also it can be seen that more added cement decrease dried specific weight. Also as shown in these figures adding 3\%cement and 3\% lime to the soil has effect on the maximum dried specific weight and optimum moisture content. The results indicate that by adding of $3 \%$ lime, the dried specific weight of soil reduced slightly after which the dried specific weight of soil increased slightly due to adding at $6 \%$ lime and $6 \%$ cement. Generally the maximum dry density of the soil-lime mixture is lower than in the soil-cement mixture. However, the maximum dry density in the treated soil is lower than in the untreated soil. Also it can be observed that, generally, the soil the optimum moisture content will be more increased due to adding lime than adding cement this result return to Flocculation and agglomeration produce a change in the texture of clay soils, clay particles tend to clump together to form larger particles, these reactions tend to decrease the dry density and increase moisture content. These results are in agreement with [9].

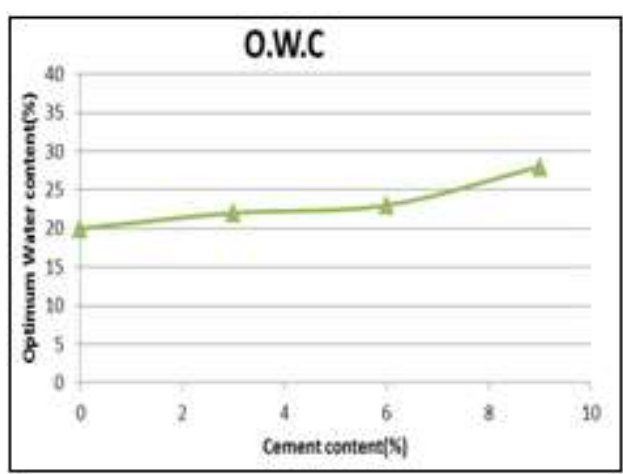

Figure 9: Optimum water content for soil-cement mixture at different percentages

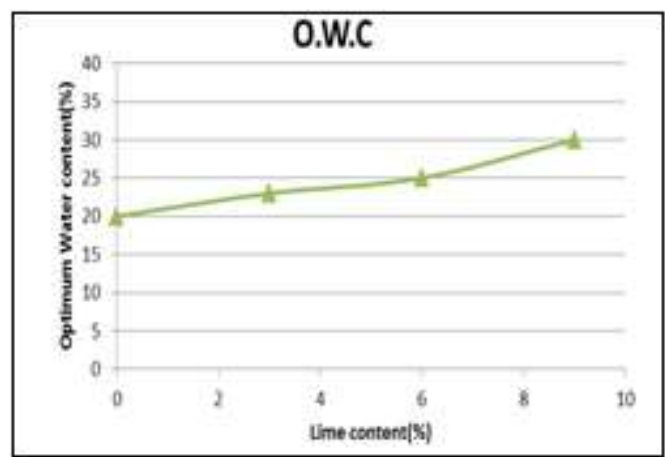

Figure 10: Optimum water content for soil-lime mixture at different percentages.

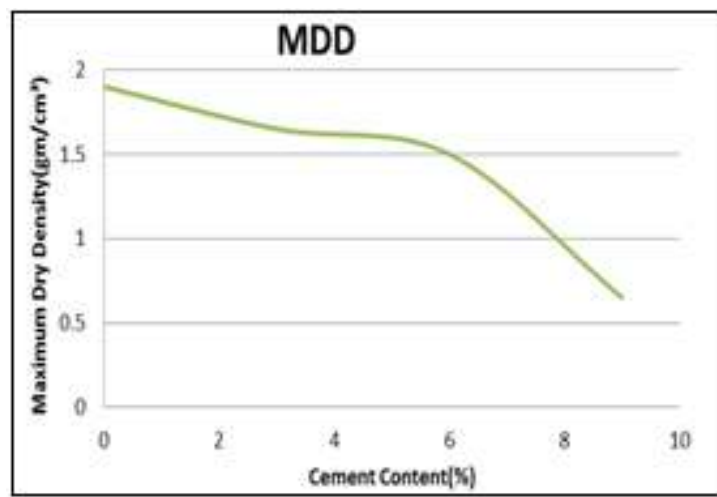

Figure 11: Maximum dry density for soil-cement mixture at different percentages.

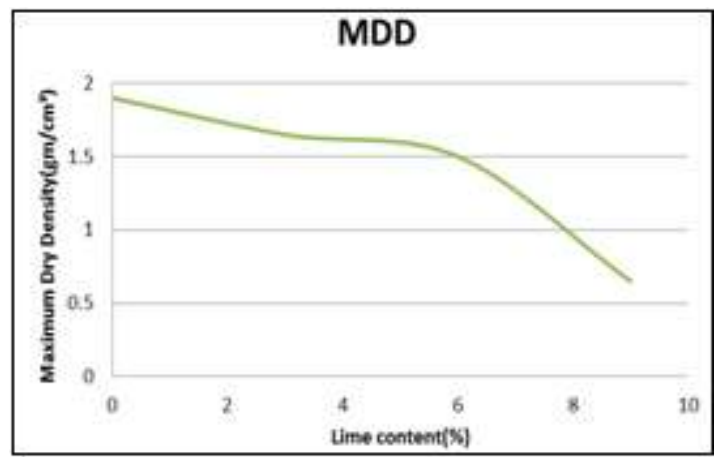

Figure 12: Maximum dry density for soil-lime mixture at different percentages.

From our result we found that cement is more effective than lime for our soil and the percent $6 \%$ is the optimum percent ,because the performance of stabilized soils is influenced by the characteristics of the original soil, type and quantity of stabilization additive and the effectiveness of the additives

\title{
Volume 6 Issue 12, December 2017
}

\author{
www.ijsr.net
}

Licensed Under Creative Commons Attribution CC BY 


\section{International Journal of Science and Research (IJSR) \\ ISSN (Online): 2319-7064 \\ Index Copernicus Value (2016): 79.57 | Impact Factor (2015): 6.391}

depends on the soil treated and the amount of additive used, this conclusions are in agreement with[10]and[11].

\section{References}

[1] Attoh-Okine, N.O., 1995. Lime treatment of laterite soils and gravels-revisited. Constr. Build. Mater., 9(5): 283-287.

[2] Azadegan, O., S.H. Jafari and J. Li, 2012. Compaction characteristics and mechanical properties of lime/cement treated granular soils. Electron. J. Geotech. Eng., 17: 2275-2284.

[3] Mallela, J., P. Harold Von Quintus, K.L. Smith and E. Consultants, 2004. Consideration of Lime-stabilized Layers in Mechanistic-empirical Pavement Design. The National Lime Association, Arlington, Virginia, USA.

[4] Ramadas, T., N.D. Kumar and G. Yesuratnam, 2011. Geotechnical characteristics of three expansive soils treated with lime and flyash. Int. J. Earth Sci. Eng., 4: 46-49.

[5] Alawaji, H.A., 2001. Settlement and bearing capacity of geogrid-reinforced sand over collapsible soil. Geotext. Geomembranes, 19(2): 75-88.

[6] Design Procedures for Soil Modification or Stabilization Production Division Office of Geotechnical Engineering 120 South Shortridge Road Indianapolis, Indiana 46219 January 2008.

[7] ARMY TM 5-822-14 (1994) "Soil Stabilization for Pavements" Departments of the Army, And the Air Force, Washington.

[8] AASHTO T-26(1979)" Standard Method of Test for Quality of Water to be Used in Concrete".

[9] National Lime Association. (2006). Technical Brief. Lime, the Versatile Chemical, pp. 1-6.

[10] Parsons Robert L.(2004)" Use of Cement Kiln Dust for Subgrade Stabilization". The Kansas Department of Transportation .Topeka, Kansas. University of Kansas.

[11] Tyndall, (2008). "Structural Evaluation Procedure for Stabilized Soil-Surfaced Airfields", Engineering Technical Letter (ETL) 08-14, Department of The Air Force Head Quarters Air Force Civil Engineer Support Agency, PP.4-16. 